\title{
Three non-indigenous species from Madeira harbors, including a new species of Parasmittina (Bryozoa)
}

\author{
Javier Souto $^{1,2}$ • Patrício Ramalhosa ${ }^{3}$ João Canning-Clode Pa,5 $^{3,4}$
}

Received: 17 February 2016 /Revised: 2 October 2016 / Accepted: 4 October 2016 / Published online: 22 October 2016

(C) The Author(s) 2016. This article is published with open access at Springerlink.com

\begin{abstract}
During a study investigating the identity and abundance of fouling non-indigenous species in marinas from the Madeira Archipelago, three species of bryozoans were detected on experimental settlement plates. These three species are described and figured. Celleporaria inaudita was previously only known from Vanuatu (South Pacific Ocean) and Safaga Bay (Red Sea). Parasmittina alba was previously only known from the Brazilian coast. The origin of Parasmitina multiaviculata sp. nov. is unknown. Secondary introduction by anthropogenic vectors (via hull fouling of recreational vessels) seems the most plausible explanation for the presence of these species in the Madeira Islands.
\end{abstract}

Communicated by A. Waeschenbach

This article is registered in ZooBank under urn:lsid:zoobank.org:pub:036799 F4-D0D9-463B-BE6D-971692E3EDF7

Javier Souto

javier.souto-derungs@univie.ac.at

1 Institut für Paläontologie, Geozentrum, Universität Wien, Althanstrasse 14, A-1090 Wien, Austria

2 Departamento de Zoología, Genética y Antropología Física, Universidad de Santiago de Compostela, Santiago de Compostela, Spain

3 MARE - Marine and Environmental Sciences Centre, Quinta do Lorde Marina, Sítio da Piedade, 9200 - 044, Caniçal, Madeira, Portugal

4 Department of Oceanography and Fisheries, Centre of IMAR of the University of the Azores, Rua Prof. Dr Frederico Machado, 4, PT-9901-862 Horta, Azores, Portugal

5 Smithsonian Environmental Research Center, Edgewater, MD 21037, USA
Keywords Non-indigenous species · Biological Invasions · Parasmittina $\cdot$ New species · Atlantic Ocean · Celleporaria

\section{Introduction}

The introduction of non-indigenous species (NIS) into new ecosystems is now considered a major environmental and economic threat and, along with habitat destruction, a leading cause of biodiversity loss at a global scale (Nentwig 2007; Canning-Clode 2015). In the marine system, the most significant vector contributing to new biological invasions is commercial shipping, particularly through the unintentional transfer of large numbers of organisms in ballast water and hull fouling (Ruiz et al. 2000).

Every hard substratum in the marine environment (e.g., artificial structures such as ship hulls, piers, pontoons, pilings, seawalls, and buoys) is subject to a process known as biofouling - the accumulation of unwanted biological material at an interface (Dobretsov et al. 2014). The organisms forming this biofouling community may vary in size from microorganisms and propagules of sessile macroorganisms to complex multispecies and multidimensional assemblages including mobile associated fauna and large macroalgae (Wahl 1997; Dürr and Thomason 2010; Dobretsov et al. 2014). In fact, one of the most ancient vectors of introduction of NIS is the transfer of fouling species such as sponges, hydrozoans, barnacles, bryozoans, mollusks, tunicates and macroalgae on ship hulls (Carlton and Hodder 1995). In this context, several new records of these groups have been found globally, particularly in marinas and harbors (e.g., Piola and Johnston 2008; CanningClode et al. 2013a, b; Zabin et al. 2014).

The Madeira Archipelago is composed of two inhabited volcanic islands - Madeira and Porto Santo - and is located southwest of continental Europe and $\sim 700 \mathrm{~km}$ off the 
Moroccan coast in the Atlantic Ocean. Historically, the main island of Madeira has offered an important port for re-fuel and rest stops for merchant and passenger ships between Europe and the Caribbean, and the American and African continents. Nowadays, most shipping can be attributed to tourist cruise ships and sailing yachts from different parts of the world (APRAM 2014). In recent years, the Madeira Archipelago has been the site of a comprehensive monitoring survey of marine NIS. As a result, several new species have been detected (e.g., Wirtz and Canning-Clode 2009; Canning-Clode et al. 2013a; Ramalhosa et al. 2014; Ramalhosa and CanningClode 2015) including previously un-described species (Souto et al. 2015). The knowledge about bryozoans from Madeira Island is far from complete, but several papers record approximately 150 species from this phylum in this area. The first papers about bryozoans from these islands date back to the end of the past century (Busk 1858a, b, 1859, 1860, 1861; Hincks 1880; Johnson 1897; Waters 1899; Norman 1909) but in recent years new records, including undescribed species and NIS, have been added (d'Hondt 1985; Alves and Cocito 2002; Berning and Kukliński 2008; Berning et al. 2008; Wirtz and Canning-Clode 2009; Berning 2012; Souto et al. 2014, 2015; Ramalhosa et al. 2016). In the present paper, we describe one new species and two new records of Bryozoa collected from artificial settlement plates as part of an ongoing monitoring survey of NIS conducted in several marinas in the Madeira Archipelago.

\section{Material and methods}

Since July 2013, we have been investigating the species composition and abundance of fouling assemblages in four marinas of the Archipelago: Calheta $\left(32^{\circ} 43^{\prime} \mathrm{N}, 17^{\circ} 10^{\prime} \mathrm{W}\right)$, Funchal (32 $\left.38^{\prime} \mathrm{N}, 16^{\circ} 54^{\prime} \mathrm{W}\right)$, Caniçal $\left(32^{\circ} 44^{\prime} \mathrm{N}, 16^{\circ} 42^{\prime}\right.$ W) and Porto Santo Island $\left(33^{\circ} 3^{\prime} \mathrm{N}, 16^{\circ} 18^{\prime} \mathrm{W}\right)$ (Fig. 1) as part of an ongoing survey of NIS in Madeira. Following the methods used by Canning-Clode et al. (2013a) and most recently by Ramalhosa et al. (2014), ten polyvinylchloride (PVC) settlement plates $(14 \times 14 \times 0.3 \mathrm{~cm})$ were individually attached to a brick in a horizontal orientation facing downwards and hung at about 1 meter depth, from pontoons in all four marinas. Settlement plates were collected every 3 months (starting in July 2013; finishing in August 2014) for fouling species identification, a duration after which fully developed colonies could be observed. Fouling communities were first observed with the aid of a stereomicroscope (Leica Wild-M3 Heerbrugg), and digital photographs were taken of specimens from settlement plates using a Sony DSC-W55 camera. For the purpose of this analysis, only bryozoan samples were collected from the plate in the different marina sites, and preserved in $95 \%$ ethanol. Bryozoan specimens were later examined with a stereomicroscopy Leica MZ12. Colony fragments were dried, and scanning electron microscope (SEM) photographs of uncoated material were taken using an FEI Inspect S50 SEM at the University of Vienna, Austria. Some samples were treated in an ultrasound bath and bleached with sodium hypochlorite prior to SEM examination. The SEM was used with a back-scattered electron detector in low vacuum mode. Zooidal measurements were taken from the SEM images using the software Image ${ }^{\circledR}$ (http://rsbweb.nih.gov/ij). Specimens were deposited in the collections of the Museu Municipal de História Natural (MMF), in Funchal, Madeira Island, Portugal.

\section{Systematics}

Phylum Bryozoa Ehrenberg, 1831

Class Gymnolaemata Allman, 1856

Order Cheilostomata Busk, 1852

Family Lepraliellidae Vigneaux, 1947

Genus Celleporaria Lamouroux, 1821

Celleporaria inaudita Tilbrook, Hayward and Gordon, 2001

(Fig. 2, Table 1)

Celleporaria inaudita Tilbrook, Hayward and Gordon, 2001: 72, Figs 13D-F

Material examined: MMF44608 and MMF44609 from Funchal, MMF44610 from Calheta and MMF44611 from Caniçal.

\section{Description}

Irregular encrusting colony, multilaminar or developing nodules. Irregular autozooids with an irregular disposition. Frontal wall finely granular, with only a few rounded, marginal pores. Primary orifice slightly wider than long, anter semicircular, poster with sides slightly concave and indented by two asymmetrical sinuses, separated by one cusp; two more cusps can appear in the lateral part of the sinus. Development and size of the orifice, the sinuses, and the cusps are very variable between autozooids, in some cases dependent on the degree of the calcification. Condyles lacking. No oral spines. Avicularia suboral on an umbo, present in some zooids, rostrum elliptical, with the distal portion denticulate. Large vicarious avicularia, cystid with rounded marginal pores similar to the ones present in the autozooid; rostrum raised, with rounded and serrated tip, sometimes externally cover by secondary calcification. Cross-bar complete, thin, without columella, palate with very large foramen. Ooecium non-cleithral, widely open; covered by granular secondary calcification.

\section{Distribution}

Known from Vanuatu (South Pacific Ocean) and Safaga Bay (Red Sea). This paper reports its first record for Madeira Island. To date, our monitoring surveys did not detect Celleporaria inaudita in Porto Santo Island.

Remarks 


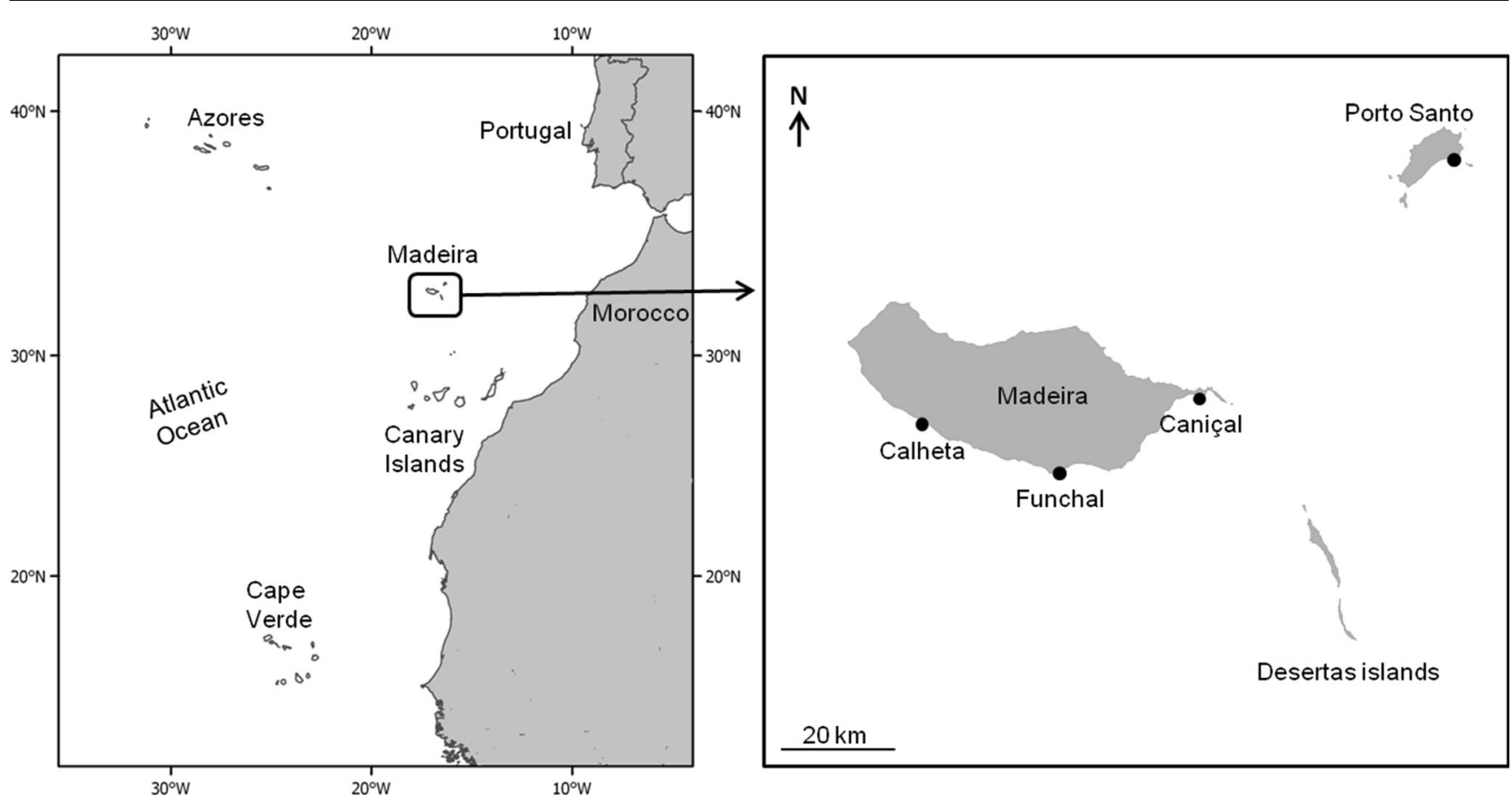

Fig. 1 Location of the four study sites where samples were collected in the Madeira archipelago

Celleporaria inaudita was described from Vanuatu as forming nodules on corals and anthropogenic structures, e.g., Port Vila harbor on Efate Island (Tilbrook et al. 2001). Ostrovsky et al. (2011) also included this species in a checklist of bryozoans from Safaga Bay (Red Sea); see figures in Ostrovsky et al. (2015). According to Tilbrook et al. (2001), C. inaudita is similar to $C$. aperta, but the latter species has oral spines and a lanceolate rostrum in the spatulate avicularium, which is absent in $C$. inaudita. The specimens collected in Madeira, as well as the specimens described by Tilbrook et al. (2001) and the Safaga Bay specimens, indicate that there is variability in several characters, not only between colonies, but also between zooids in the same colony. The morphology of the orifice is very variable, and although the presence of the two asymmetrical sinuses is constant, their morphology is very variable and the smaller sinus can be very reduced. Here we figured the denticulation of the rostrum of the spatulate avicularia, not visible in the Safaga Bay collection, was probably due to erosion of the specimens. Similarly, the lyrula is very variable and not a good taxonomic character (see, for example, Kuklinski et al. 2013; Berning et al. 2014). The morphology of the orifice in general, and the sinus in particular can be very variable in some species of Celleporaria, both between colonies and within the same colony; see the case of Celleporaria brunnea (Hincks, 1884) (Canning-Clode et al. 2013b; Harmelin 2014; Lodola et al. 2015). Therefore, orifice morphology is not a very useful taxonomic character for this genus. In 2006 and 2007, CanningClode et al. (2013a) collected specimens at Quinta do Lorde Marina that were identified as Celleporaria cf. inaudita; thus, this new record confirms its identification, and its presence across the marinas of Madeira island.

Family Smittinidae Levinsen, 1909

Genus Parasmittina Osburn, 1952

Parasmittina alba Ramalho, Muricy and Taylor, 2011

(Fig. 3, Table 2)

Parasmittina alba Ramalho, Muricy and Taylor, 2011: 769, Fig. 2.

Material examined: MMF44612 from Caniçal, MMF44613 and MMF44614 from Calheta, MMF44615 from Porto Santo.

\section{Description}

Colony encrusting, unilaminar or multilaminar, pale white in color. Autozooids mainly rectangular, in some cases hexagonal, longer than wide, disposed initially in linear series; linear pattern in old colonies lost. Frontal wall coarse, imperforate centrally, and with large marginal pores. Primary orifice wider than long, surrounded by a proximo-lateral peristome, incomplete proximally, with a proximal fissure usually quadrangular. Distal edge round, with two curved, thin, and pointed condyles, curved and directed to the lyrula. In ovicellate zooids, the distal margin of the orifice has two symmetrical notches that could be more or less developed. Wide lyrula in the proximal border. One or two spines in the distal margin of the orifice. Three kinds of adventitious avicularia. In most cases only one per zooid (although two in some cases), located latero-proximal to the orifice. Although, there are large areas in the colony without avicularia. Avicularia are small oval, very abundant, variable in size and form, generally longer than wide and with the distal margin rounded and wider than the 
Fig. 2 Celleporaria inaudita. a General aspect of the colony surface, with vicarious avicularia. b Autozooid orifices, vicarious avicularia and ooecia. c Ooecia in unbleached specimen. $\mathbf{d}$ Vicarious avicularia. $\mathbf{e}, \mathbf{f}, \mathbf{g}, \mathbf{h}$ Morphological variability between orifices and suboral avicularia
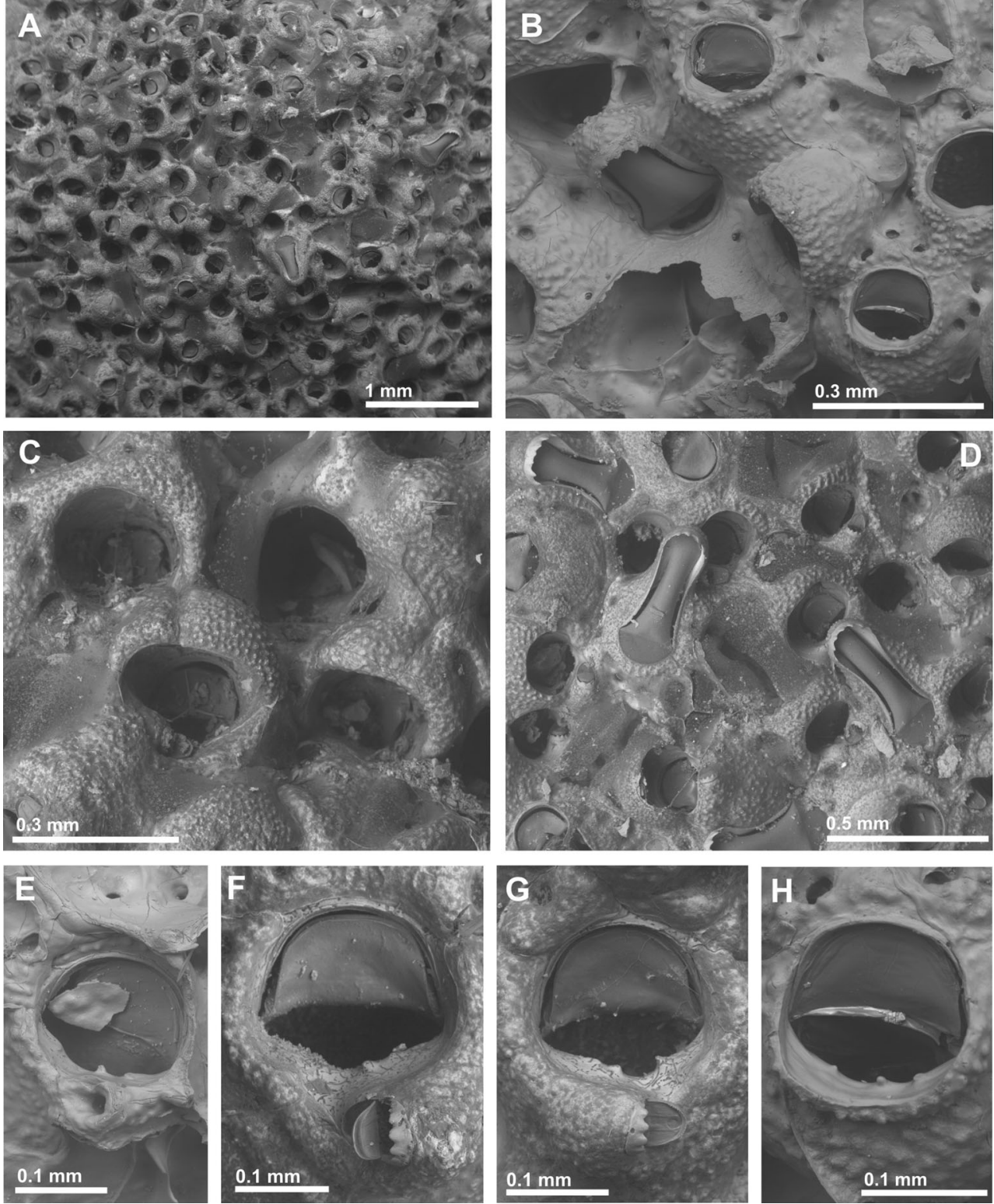

proximal portion. Small triangular avicularia directed to the margin of the zooid, lightly raised, and with the margins slightly serrated. Large, spatulate avicularia not common, situated close to the orifice and directed proximally, rostrum

elongated and spatulate of variable morphology, covering almost the whole frontal wall of the zooid. Ovicell hyperstomial, ooecium formed by the distal autozooid, globular, about as wide as long, ectooecium perforated by
Table 1 Measurements (in mm) of Celleporaria inaudita

\begin{tabular}{llllll}
\hline & Mean & SD & Minimum & Maximum & $N$ \\
\hline Zooidal orifice length & 0.147 & 0.0107 & 0.126 & 0.169 & 19 \\
Zooidal orifice width & 0.169 & 0.0168 & 0.147 & 0.204 & 19 \\
Spatulate avicularia length & 0.430 & 0.0148 & 0.411 & 0.448 & 6 \\
Spatulate avicularia width & 0.192 & 0.0110 & 0.175 & 0.204 & 6 \\
Ooecium length & 0.130 & 0,0186 & 0,094 & 0,175 & 11 \\
Ooecium width & 0.275 & 0.0191 & 0.228 & 0.299 & 11 \\
\hline
\end{tabular}

$S D$ standard deviation, $N$ number of measurements 
Fig. 3 Parasmittina alba. a General view of the colony margin. b Autozooid orifice, with condiles and the base of oral spines. c Autozooids with lateral small triangular avicularia. d Autozooids with latero-suboral oval avicularia. e Spatulate avicularia. f, $\mathbf{g}$ Ovicellate zooids with variability in the morphology of the ooecia. $\mathbf{h}$ Detail of ovicell; arrows indicate symmetrical notches in the distal margin of the orifice
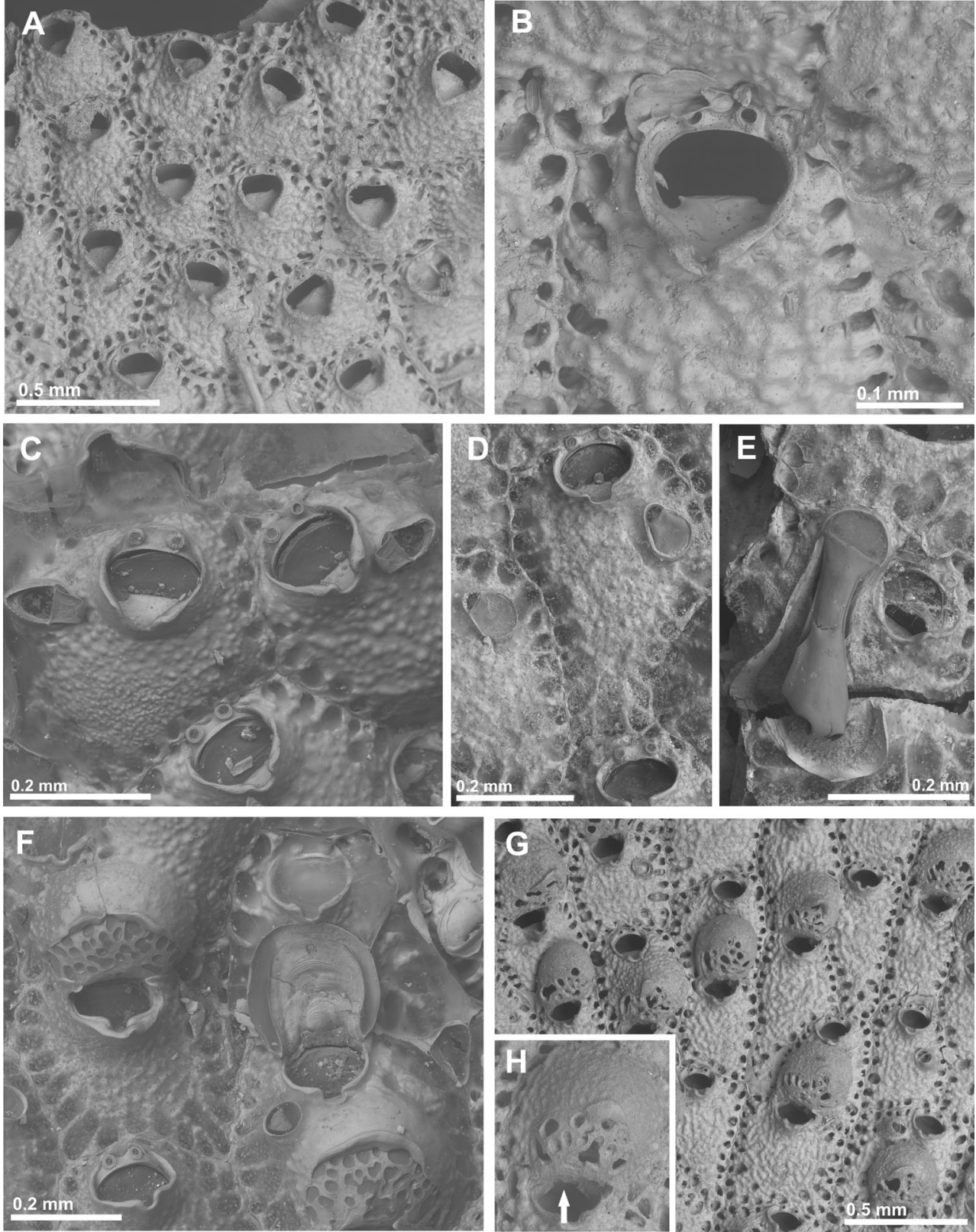

numerous, although variable in number, irregularly-shaped pseudopores. Secondary calcification very variable in development, covering the distal and lateral portions of the ovicell, the ectooecium visible only in the circular frontal-proximal area.

\section{Distribution}

Only known previously from Arraial do Cabo, Rio de Janeiro, Brazil. Now present in Porto Santo and Madeira Island (Calheta and Caniçal), Portugal.

\section{Remarks}

The specimens found in Madeira fully match the morphological characteristics given for Parasmittina alba. This species was described from Arraial do Cabo in Rio de Janeiro, Brazil (Ramalho et al. 2011) and had not been recorded elsewhere until now. Some differences are noted between the original material and our specimens; mainly in the figured ovicells (Ramalho et al. 2011: Fig. 2b, h), which have large pores in the ectooecium, but are smaller in our specimens. This difference could be attributed to the variability of this structure and difference in level of calcification, as was observed by us between colonies and even between ovicells in the same colony (Fig. 3f, g, h). Madeira specimens have two symmetrical notches in the distal margin of the orifice in ovicellate zooids (Fig. 3h); this structure was also noted in P. alba from Arraial do Cabo (Fig. $2 \mathrm{~g}$ and $\mathrm{h}$ in Ramalho et al. 2011), although comments about this 
Table 2 Measurements (in $\mathrm{mm}$ ) of Parasmittina alba

\begin{tabular}{llllll}
\hline & Mean & SD & Minimum & Maximum & $N$ \\
\hline Zooidal length & 0.488 & 0.0697 & 0.390 & 0.670 & 24 \\
Zooidal width & 0.340 & 0.0580 & 0.240 & 0.460 & 24 \\
Primary orifice length & 0.082 & 0.0056 & 0.076 & 0.101 & 20 \\
Primary orifice width & 0.125 & 0.0102 & 0.103 & 0.143 & 20 \\
Oval avicularia length & 0.092 & 0.0095 & 0.074 & 0.104 & 9 \\
Oval avicularia width & 0.056 & 0.0037 & 0.051 & 0.063 & 9 \\
Pointed avicularia length & 0.078 & 0.0067 & 0.068 & 0.089 & 10 \\
Pointed avicularia width & 0.047 & 0.0050 & 0.037 & 0.054 & 10 \\
Ooecium length & 0.265 & 0.0177 & 0.235 & 0.297 & 20 \\
Ooecium width & 0.267 & 0.0184 & 0.233 & 0.300 & 20 \\
\hline
\end{tabular}

$S D$ standard deviation, $N$ number of measurements were not included in the original description. Only one avicularium per autozooid is indicated in the original description, while two triangular avicularia were observed in one ovicellate zooid, but this seems very infrequent. In addition, the adventitious avicularia were not seen in our specimens.

This species is very similar to Parasmittina betamorphaea Winston 2005, distributed in the Gulf of Mexico and Brazil. But according to Ramalho et al. (2011) Parasmittina alba is differentiated by the presence of more than one avicularium per zooid in $P$. betamorphaea, lacking the serrated rostrum in small avicularia, possessing the giant avicularia with a more rounded rostrum, and by the different positioning and shape of the pores in the ovicell. Much of the difference between these species, in the ovicell and avicularia morphology, is attributed to characters that are very variable between colonies or even between zooids in the same colony. In the figures of the original description of $P$. betamorphaea, it is not possible to see more than one avicularium per zooid. Both species, $P$ alba and $P$. betamorphaea, were described from only two colonies, which indicates that more specimens should be studied more carefully, particularly to examine the intra-colonial variability and to evaluate the possibility of the two species being synonyms.

\section{Parasmittina multiaviculata sp. nov.}

(Fig. 4, Table 3)

Material examined: Holotype: MMF44616 from Porto Santo; Paratype: MMF44617 from Porto Santo.

Etymology: In reference to the numerous avicularia per zooid.

\section{Description}

Colony encrusting, unilaminar or multilaminar, initially translucent. Rectangular to hexagonal autozooids in the first layer and more irregular in the second layers. Frontal wall nodular, with marginal large pores. Orifice longer than wide, surrounded by a normally rectangular (but very variable in morphology, and more rounded in ovicellated zooids) peristome, laterally more developed, proximally poorly developed and distally interrupted by one (in some cases two) distal spines. This peristome is not visible when the secondary calcification is more developed. Proximal border of the orifice with a variable lyrula, usually short and occupying from one quarter to two third of the proximal border. Condyles stout, sharply pointed. Avicularia monomorphic, oval (lightly pointed when is in direct contact with the margin of the zooid), very numerous in some parts of the colony, but always two or more per zooid. The avicularia occur on the margins of the zooids. Rostrum is slightly spatulate. Ovicell subimmersed, and becoming endozooidal because of the strong secondary calcification. Ooecium formed by the distal autozooid. Ectooecium almost flat frontally, with several irregularly-shaped pseudopores. The secondary calcification covers the distal, lateral and, in some cases, the proximal part of the ectooecium, leaving only a central area with exposed pseudopores. In some ovicells only the peripheral area of the secondary calcification is truly calcified, whereas the rest is membraneous, in cleaned specimens showing the ectooecium with pseudopores underneath.

Distribution

Currently only known from Porto Santo Island, Madeira, Portugal.

Remarks

According to the literature, only two species of this genus were previously recorded in Madeira, Parasmittina trispinosa (Johnston, 1825) by Waters (1899) and Norman (1909) and Parasmittina protecta (Thornely, 1905) by Canning-Clode et al. (2013a). The two colonies reported in the current study show significant differences from these two species and from the previously described species, $P$. alba. According to Harmelin et al. (2009), P. protecta presents a peristome interrupted distally, and raised proximally; the orifice is broader than high, and the avicularia are infrequent and when present, they occur in two morphologies and are 
Fig. 4 Parasmittina

multiaviculata sp. nov. a General view of the autozooids and ooecia in an unbleached specimen. b Bleached specimen, showing ooecia and abundant frontal avicularia. c Ovicellate zooids and frontal avicularia. $\mathbf{d}, \mathbf{e}$ Primary orifice with variations in the lyrula morphology. f Condile. g Bleached ovicellate and non ovicellate zooids. h Ovicellate zooid in unbleached specimen
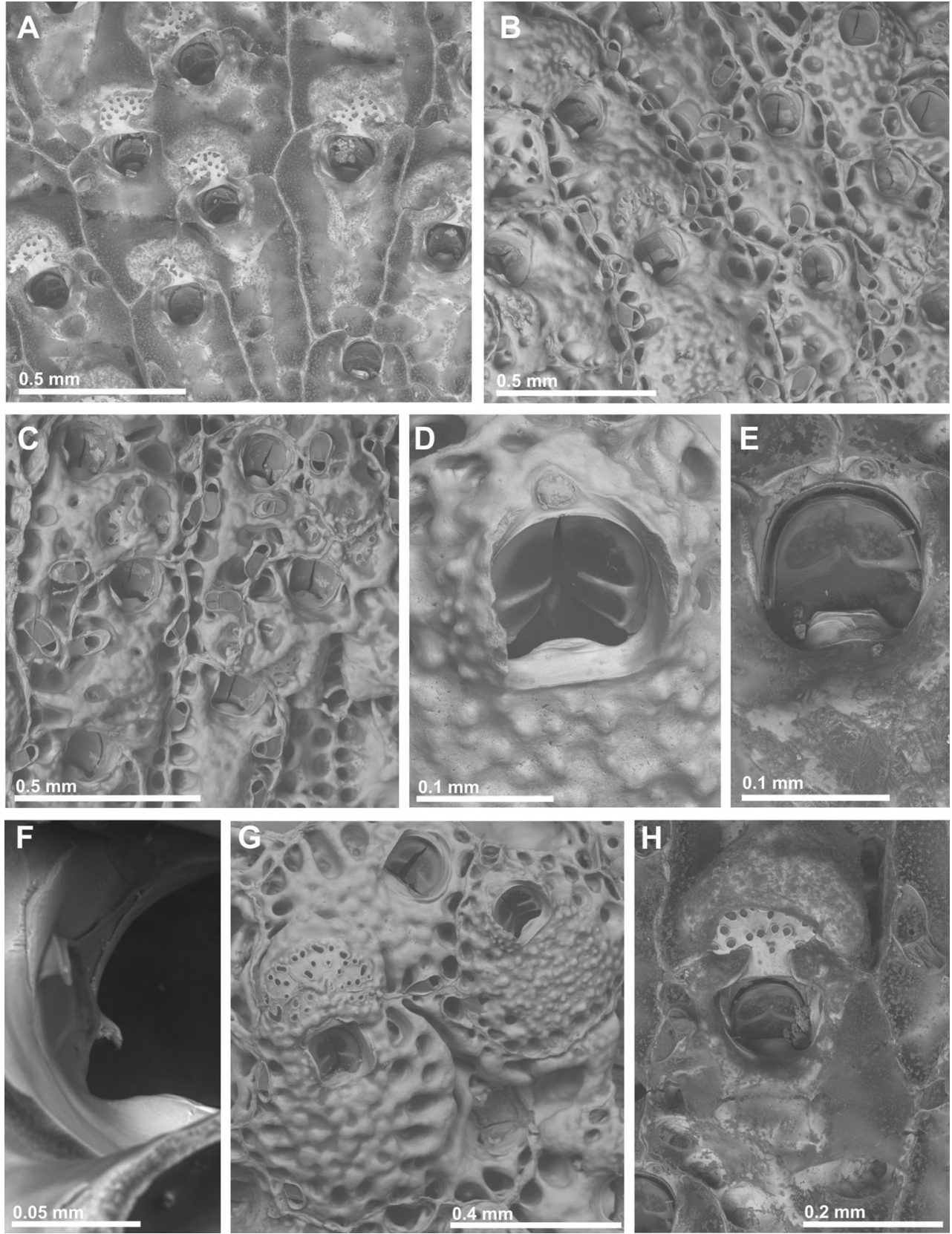

large. According to the descriptions by Hayward and Ryland (1999) and Soule and Soule (2002), $P$. trispinosa presents an orbicular orifice with a big triangular avicularium lateral to the orifice, which is, in some cases, replaced by a smaller avicularium. Furthermore, the ovicells in P. trispinosa are characterized by having few, irregular large pores.

The genus Parasmittina is very specious with currently 122 known species (Bock 2015a; WoRMS 2015), distributed around all oceans, but with a high number of species in the Pacific and Indian Oceans. Among this diversity, there are few species that have an orifice that is longer than wide, monomorphic avicularia, and one or two distal oral spines. Madeira specimens are similar to Parasmittina inalienata Tilbrook 2006, described from the Solomon and Fiji Islands; but differ from that species by having a slightly bigger orifice with a wider lyrula, (Fig. 35D in Tilbrook 2006), less globular ovicells which are almost flat in the frontal plane, and by lacking a round peristome in the ovicellate zooids. The avicularia of $P$. inalienata seem to be numerous with a slightly spatulate rostrum which is always directed proximo-medially or medially, while in the Madeira specimens, the direction of the rostrum is disordered, without a clear pattern, and the rostrum in some cases is slightly pointed.

Most species of this genus (c. 99 species) seem to be natives from the Pacific and Indian Oceans (e.g., 
Table 3 Measurements (in $\mathrm{mm}$ ) of Parasmittina multiaviculata sp nov

\begin{tabular}{llllll}
\hline & Mean & SD & Minimum & Maximum & $N$ \\
\hline Zooidal length & 0.576 & 0.0719 & 0.464 & 0.720 & 14 \\
Zooidal width & 0.366 & 0.0392 & 0.307 & 0.429 & 14 \\
Primary orifice length & 0.110 & 0.0076 & 0.093 & 0.124 & 14 \\
Primary orifice width & 0.081 & 0.0081 & 0.079 & 0.109 & 14 \\
Avicularia length & 0.103 & 0.0161 & 0.065 & 0.130 & 18 \\
Avicularia width & 0.050 & 0.0082 & 0.036 & 0.062 & 18 \\
Ooecium length & 0.218 & 0.0125 & 0.198 & 0.241 & 18 \\
Ooecium width & 0.275 & 0.0158 & 0.249 & 0.297 & 18 \\
\hline
\end{tabular}

$S D$ standard deviation, $N$ number of measurements
Tilbrook et al. 2001; Tilbrook 2006; Soule and Soule 1973, 2002; Gordon 1984, 1989; Hayward 1988; Bock 2015a; Seo 2002; Hayward and Parker 1994), and are particularly abundant in coral reef habitats (Hayward and Parker 1994). Several other Parasmittina species identified or recorded from other oceans and seas are considered non-indigenous (e.g., Harmelin et al. 2009). The exclusive presence of Parasmittina multiaviculata sp. nov. on artificial plates deployed in harbors in Madeira, and the fact that there are no previous records of similar species in the area, suggests this could be a new introduction. The presence of this species in only one locality may indicate a recent introduction. Its morphological proximity to $P$. inalienata could indicate Parasmittina multiaviculata sp. nov. may have a Pacific origin.

\section{Discussion}

Knowledge of the Madeira marine invertebrate fauna is scarce and in the case of bryozoans, very limited (Busk 1858a, b, 1859, 1860, 1861; Hincks 1880; Johnson 1897; Waters 1899; Norman 1909). However, in recent years, monitoring surveys for non-indigenous species in the archipelago has resulted in new records and undescribed species in the islands (d'Hondt 1985; Alves and Cocito 2002; Berning and Kukliński 2008; Berning et al. 2008; Wirtz and Canning-Clode 2009; Berning 2012; Souto et al. 2014, 2015; Ramalhosa et al. 2016). Nevertheless, the lack of a comprehensive checklist of bryozoans in Madeira makes the detection and dating of new anthropogenic introductions a complex challenge. Due to the sessile mode of life of their adults and the estimated shortlived non-feeding pelagic phase of their larvae, the presence of the three species reported here in Madeiran waters is difficult to explain by natural dispersion methods, so anthropogenic vectors seem more reasonable. The presence in other substrates different from the settlement panels (natural or artificial) was not checked, so no inferences can be made regarding the extent by which these species have established themselves in the natural environment.

The natural fauna of Madeira shows close affinities with the fauna of Lusitania, Mediterranean, and Mauritanian regions (Wirtz 1998); nevertheless, the three species of bryozoans found here show closer affinities with species from the Pacific (C. inaudita, P. multiaviculata sp. nov.) and the Caribbean (P.alba). Several Brazilian and Caribbean species of macroinvertebrates were detected in recent years in Madeiran waters (e.g., Wirtz and Canning-Clode 2009; Canning-Clode et al. 2013a, b; Ramalhosa et al. 2014; Souto et al. 2015). Beania maxilladentata Ramalho, Muricy and Taylor 2008, a bryozoan only previously known from Brazil (Ramalho et al. 2008; Vieira et al. 2010), was also found in Madeiran waters (Souto et al. 2015), but in this case, only on natural substrates. In addition, several other species with West Atlantic distributions, mainly from the Gulf of Mexico, were also recently found in Madeira (Canning-Clode et al. 2013a; Ramalhosa et al. 2014) such as the bryozoans Schizoporella pungens (Canu and Bassler 1928), Cradoscrupocellaria bertholetti (Audouin 1826), Amathia verticillata (Delle Chiaje 1822), the ascidian Distaplia corolla Monniot F. 1974 and the sabellid polychaete Branchiomma bairdi (McIntosh 1885). Also a few species from the Indo-Pacific region were detected (Norman 1909; Canning-Clode et al. 2013a; Ramalhosa et al. 2014; Ramalhosa and CanningClode 2015), but most of these species appeared first in European waters (e.g., Cabezas et al. 2015; Arias et al. 2013; Cinar 2009; Giangrande et al. 2013; Garcia Raso 1981; Turon et al. 2005; Ryland et al. 2009, 2011). Nevertheless, none of the three species reported in the current paper were recorded in other areas close to Madeira. Of them, only Celleporaria inaudita was recently found in the Red Sea, after its original description in the Pacific Ocean. The direct introduction of these species from their original localities to Madeira seems not very plausible. It is possible that these species have a broader distribution than currently known, particularly in European and North African waters, and have been probably introduced to Madeira via hull fouling (recreational 
and/or cruise vessels). Currently, most shipping can be attributed to tourist cruise ships and sailing yachts visiting for refuel and rest stops from different parts of the world (APRAM 2014). Furthermore, recent findings by Ramalhosa et al. (2016) have shown that dry dock inspections on local and foreign recreational vessels support the hypothesis from other studies, that emphasize hull fouling as the key introduction vector that contribute to the arrival and spread of NIS to neighbouring islands. Moreover, the genus Parasmittina is a very specious genus with currently 122 known species (Bock 2015a; WoRMS 2015) and 17 fossil species. Similar diversity is present in the Celleporaria genus, with 90 species (Bock 2015b). This large number of species in these genera makes correct identification challenging, possibly resulting in some species being misidentified and lumped together. So records in other parts of the world of these species could go unnoticed.

Here, three species of bryozoans are added to the nine other non-indigenous bryozoan species known from the Madeira archipelago (Wirtz and Canning-Clode 2009; Canning-Clode et al. 2013a; Ramalhosa et al. 2016). Currently, the xenodiversity in Madeira Island is probably underestimated, and therefore this number is likely to increase in the next years.

Acknowledgments Open access funding provided by Univeristy of Vienna.

We are grateful to Oscar Reverter-Gil and Linda McCann for the valuable revision of an earlier version of this manuscript. Thanks also to Kevin Tilbrook and Andrew Ostrovsky for their comments that helped to improve this paper. The work of J.S. was supported by the Austrian Science Fund (FWF, Lise Meitner Program M1444-B25 and Project Number AP28954-B29). P. Ramalhosa holds a research fellowship in the Project M1420-01-0145-FEDER-000001 — project Observatório Oceânico da Madeira (OOM). J. Canning-Clode was supported by a starting grant in the framework of the 2014 FCT Investigator Programme (IF/01606/2014/CP1230/CT0001). We thank Porto Santo Line for their travel aid to the Island of Porto Santo, and the administration of the four marinas monitored in this study (Porto Recreio da Calheta, Marina do Funchal, Marina da Quinta do Lorde and Marina do Porto Santo). This is contribution number 32 of the Marine Biology Station of Funchal. Finally, we are grateful to the anonymous reviewers and Dr A. Waeschenbach for their valuable revision and comments.

Open Access This article is distributed under the terms of the Creative Commons Attribution 4.0 International License (http:// creativecommons.org/licenses/by/4.0/), which permits unrestricted use, distribution, and reproduction in any medium, provided you give appropriate credit to the original author(s) and the source, provide a link to the Creative Commons license, and indicate if changes were made.

\section{References}

Alves FMA, Cocito S (2002) A new bryozoan record (Bugula calathus minor) for the marine fauna of Madeira Island (NE Atlantic). Bocagiana 204:1-5

APRAM (2014) Administração dos Portos da Região Autónoma da Madeira, SA http://www.portosdamadeira.com/index2. $\mathrm{php}$ t $=2 \& \mathrm{l}=\mathrm{pt}$
Arias A, Giangrande A, Gambi MC, Anadon N (2013) Biology and new records of the invasive species Branchiomma bairdi (Annelida: Sabellidae) in the Mediterranean Sea. Mediterr Mar Sci 14:162-171

Berning B (2012) Taxonomic notes on some Cheilostomata (Bryozoa) from Madeira. Zootaxa 3236:36-54

Berning B, Kukliński P (2008) North-east Atlantic and Mediterranean species of the genus Buffonellaria (Bryozoa, Cheilostomata): implications for biodiversity and biogeography. Zool J Linn Soc 152: 537-566. doi:10.1111/j.1096-3642.2007.00379.x

Berning B, Tilbrook KJ, Rosso A (2008) Revision of the north-eastern Atlantic and Mediterranean species of the genera Herentia and Therenia (Bryozoa: Cheilostomata). J Nat Hist 42:1509-1547

Berning B, Tilbrook KJ, Ostrovsky AN (2014) What, if anything, is a lyrula? In: Rosso A, Wyse Jackson PN, Porter JS (eds) Bryozoan Studies, Museo delle Scienze, Trento pp 21-28

Bock P (2015) Recent and fossil Bryozoa: Parasmittina Osburn, 1952. Available from: http://www.bryozoa.net/cheilostomata/smittinidae/parasmittina.html. Accessed 16 September 2015)

Bock P (2015) Celleporaria Lamouroux, 1821. In: Bock P, Gordon D (2015) World List of Bryozoa. Accessed through: World Register of Marine Species at http://www.marinespecies.org/aphia.php?p= taxdetails\&id=205020. Accessed 16 June 2016

Busk G (1858a) Zoophytology. On some Madeiran Polyzoa. Quart J Micros Sci 6:124-130

Busk G (1858b) Zoophytology. On some Madeiran Polyzoa. Quart J Micros Sci 6:261-263

Busk G (1859) Zoophytology. On some Madeiran Polyzoa. Quart J Micros Sci 7:65-67

Busk G (1860) Zoophytology. Catalogue of the Polyzoa collected by J.Y. Johnson, Esq., at Madeira, in the years 1859 and 1860, with descriptions of new species. Quart J Micros Sci 8(213-214):280-285

Busk G (1861) Description of new Polyzoa collected by J.Y.Johnston Esq., at Madeira. Quart J Micros Sci New Ser 1:77-80

Cabezas MP, Xavier R, Branco M, Santos AM, Guerra-García JM (2015) Invasion history of Caprella scaura Templeton, 1836 (Amphipoda: Caprellidae) in the Iberian Peninsula: multiple introductions revealed by mitochondrial sequence data. Biol Invasions 16:22212245

Canning-Clode J (2015) General introduction: aquatic and terrestrial biological invasions in the 21 st century. In: Canning-Clode J (ed) Biological invasions in changing ecosystems: vectors, ecological impacts, management and predictions. De Gruyter Open, Berlin, pp 13-20

Canning-Clode J, Fofonoff P, McCann L, Carlton JT, Ruiz G (2013a) Marine invasions on a subtropical island: fouling studies and new records in a recent marina on Madeira Island (East Atlantic Ocean). Aquat Invasion 8:261-270

Canning-Clode J, Souto J, McCann L (2013b) First record of Celleporaria brunnea (Bryozoa: Lepraliellidae) in Portugal and in the East Atlantic. Mar Biodivers Rec 6, e108

Carlton JT, Hodder J (1995) Biogeography and dispersal of coastal marine organisms: experimental studies on a replica of a 16th-century sailing vessel. Mar Biol 121:721-730

Cinar ME (2009) Alien polychaete species (Annelida: Polychaeta) on the southern coast of Turkey (Levantine SEA, eastern Mediterranean), with 13 new records for Mediterranean Sea. J Nat Hist 43:22832328

Dobretsov S, Williams DN, Thomason JC (2014) Biofouling methods. Wiley-Blackwell, Oxford

Dürr S, Thomason JC (2010) Biofouling. Wiley-Blackwell, Oxford

Garcia Raso JE (1981) Presencia de Pisa carinimana Miers 1879 (Crustacea, Decapoda) en las cosatas de la Península Ibérica. Arquivos do Museo Bocage Serie B 1:173-179

Giangrande A, Cosentino A, Presti C, Licciano M (2013) Sabellidae (Annelida) from the Faro coastal lake (Messina, Ionian Sea), with 
the first record of the invasive species Branchiomma bairdi along the Italian coast. Mediterran Mar Sci 13:283-293

Gordon DP (1984) The marine fauna of New Zealand: Bryozoa: Gymnolaemata from the Kermadec Ridge. NZ Oceanogr Inst Mem 91:1-198

Gordon DP (1989) The marine fauna of New Zealand: Bryozoa: Gymnolaemata (Cheilostomida Ascophorina) from the western south Island continental shelf and slope. NZ Oceanogr Inst Mem 97:1-158

Harmelin JG (2014) Alien bryozoans in the eastern Mediterranean Seanew records from the coast of Lebanon. Zootaxa 3893:301-308

Harmelin JG, Bitar G, Zibrowius H (2009) Smittinidae (Bryozoa, Cheilostomata) from coastal habitats of Lebanon (Mediterranean Sea), including new and non-indigenous species. Zoosystema 31: 163-187

Hayward PJ (1988) Mauritian Cheilostome Bryozoa. J Zool 215:269-356

Hayward PJ, Parker SA (1994) Notes on some species of Parasmittina Osburn, 1952 (Bryozoa: Cheilostomatida). Zool J Linn Soc 110:5375

Hayward PJ, Ryland JS (1999) Cheilostomatous Bryozoa. Part 2. Hippothoidea - Celleporoidea. Synopses of the British fauna. New Series 14:1-416

Hincks T (1880) Contributions towards a general history of the marine Polyzoa. Part I. Madeiran Polyzoa. Ann Mag Nat Hist, Series 5 6: 69-80

d'Hondt JL (1985) Brachiopodes et Bryozoaires (Musorstom II). Mémoires du Muséum National d'Histoire Naturelle 133:519-525

Johnson JY (1897) New cyclostomatous Bryozoa found at Madeira. Ann Mag Nat Hist, Series 6 20:60-65

Kuklinski P, Taylor PD, Denisenko NV, Berning B (2013) Atlantic origin of the Arctic biota? Evidence from phylogenetic and biogeographical analysis of the cheilostome bryozoan genus Pseudoflustra. PLoS ONE 8, e59152

Lodola A, Ferrario J, Occhipinti-Ambrogi A (2015) Further Mediterranean expansion of the non-indigenous bryozoan Celleporaria brunnea: multiple records along the Italian coasts. Sci Mar 79:263-274

Nentwig W (2007) Biological invasions: why it matters. In: Nentwig W (ed) Biological Invasions. Springer, Berlin, pp 1-6

Norman A (1909) The Polyzoa of Madeira and neighbouring islands. Zool J Linn Soc 30:275-314

Ostrovsky A, Cáceres-Chamizo JP, Vávra N, Berning B (2011) Bryozoa of the Red Sea: history and current state of research. In: Wyse Jackson PN, Spencer Jones ME (eds) Annals of Bryozoology 3: aspects of the history of research on bryozoans. International Bryozoology Association, Dublin, pp 67-98

Ostrovsky A, Cáceres-Chamizo JP, Vávra N (2015) Bryozoan collection from the Northern Bay of Safagab (Red Sea). Available from: https://www.univie.ac.at/Palaeontologie/Sammlung/Bryozoa/Safaga Bay/Safaga Bay.html. Accessed 18 September 2015

Piola RF, Johnston EL (2008) Pollution reduces native diversity and increases invader dominance in marine hard-substrate communities. Div Distr 14:329-342

Ramalho LV, Muricy G, Taylor PD (2008) Taxonomy of Beania Johnston, 1840 (Bryozoa, Flustrina) from Arraial do Cabo, Río de Janeiro State, Brazil. Arquivos do Museu Nacional 66:499-508

Ramalho LV, Muricy G, Taylor PD (2011) Taxonomic revision of some lepraliomorph cheilostome bryozoans (Bryozoa: Lepraliomorpha) from Rio de Janeiro State, Brazil. J Nat Hist 45:767-798

Ramalhosa P, Canning-Clode J (2015) The invasive caprellid Caprella scaura Templeton, 1836 (Crustacea: Amphipoda: Caprellidae) arrives on Madeira Island, Portugal. BioInvasions Rec 4:97-102

Ramalhosa P, Camacho-Cruz K, Bastida-Zavala R, Canning-Clode J (2014) First record of Branchiomma bairdi McIntosh, 1885 (Annelida: Sabellidae) from Madeira Island, Portugal (northeastern Atlantic Ocean). BioInvasions Rec 3:235-239. doi:10.3391/bir.2014.3.4.04

Ramalhosa P, Souto J, Canning-Clode J (2016) Diversity of Bugulidae (Bryozoa, Cheilostomata) colonizing artificial substrates in the Madeira Archipelago (NE Atlantic Ocean). Helgoland Mar Res. doi:10.1186/s10152-016-0465-8

Ruiz GM, Fofonoff PW, Carlton JT, Wonham MJ, Hines AH (2000) Invasion of coastal marine communities in North America: Apparent patterns, processes, and biases. Ann Rev Ecol Syst 31: 481-531

Ryland JS, de Blauwe H, Lord R, Mackie J (2009) Recent discoveries of alien Watersipora (Bryozoa) in Western Europe, with redescriptions of species. Zootaxa 2093:43-59

Ryland JS, Bishop JDD, de Blauwe H, El Nagar A, Minchin D, Wood CA, Yunnie ALE (2011) Alien species of Bugula (Bryozoa) along the Atlantic coasts of Europe. Aquat Invasions 6:17-31

Seo JE (2002) A new parasmittinid bryozoan (Cheilostomata) from Korea. Korean J Bio Sci 6:41-43

Soule DF, Soule JD (1973) Morphology and speciation of Hawaiian and eastern Pacific Smittinidae (Bryozoa, Ectoprocta). Bull Am Mus Nat Hist 152:365-440

Soule DF, Soule JD (2002) The Eastern Pacific Parasmittina trispinosa Complex (Bryozoa, Cheilostomatida): new and previously described species. Irene McCulloch Foundation Monograph series 5: $1-40$

Souto J, Reverter-Gil O, Ostrovsky AN (2014) New species of Bryozoa from Madeira associated with rhodoliths. Zootaxa 3795:135-151

Souto J, Kaufmann M, Canning-Clode J (2015) New species and new records of bryozoans from shallow waters of Madeira Island. Zootaxa 3925:581-593

Tilbrook KJ (2006) Cheilostomatous Bryozoa from the Salomon Islands. Santa Barbara Mus Nat Hist Monographs 4 (Studies in Biodiversity Number 3):1-386

Tilbrook KJ, Hayward PJ, Gordon DP (2001) Cheilostomatous Bryozoa from Vanuatu. Zool J Linn Soc 131:35-109

Turon X, Nishikawa T, Rius M (2005) Spread of Microcosmus squamiger (Ascidiacea : Pyuridae) in the Mediterranean Sea and adjacent waters. J Exp Mar Biol Ecol 342:185-188

Vieira LM, Migotto AE, Winston JE (2010) Shallow-water species of Beania Johnston, 1840 Bryozoa, Cheilostomata) from the tropical and subtropical Western Atlantic. Zootaxa 2550:1-20

Wahl M (1997) Living attached: aufwuchs, fouling, epibiosis. In: Nagabhushanam R, Thompson M (eds) Fouling organisms of the Indian Ocean: biology and control technology. Oxford \& IBH Publishing Company, New Dehli

Waters AW (1899) Bryozoa from Madeira. J Royal Microscopical Soc 1899:6-16

Winston JE (2005) Re-description and revision of Smitt's "Floridan Bryozoa" in the collection of the Museum of Comparative Zoology, Harvard University. Virg Mus Nat Hist in association with the Smithsonian Institution. Mem 7:1-148

Wirtz P (1998) Twelve invertebrate and eight fish species new to the marine fauna of Madeira, and a discussion of the zoogeography of the area. Helgolander Meeresunters 52:197-207

Wirtz P, Canning-Clode J (2009) The invasive bryozoan Zoobotryon verticillatum has arrived at Madeira Island. Aquat Invasions 4: $669-670$

WoRMS (2015) Parasmittina Osburn, 1952. In: Bock P, Gordon D (2015) World List of Bryozoa. Accessed through: World Register of Marine Species at http://www.marinespecies.org/aphia.php?p= taxdetails\&id $=110978$ on 2015-06-16

Zabin C, Ashton G, Brown CW, Davidson IC, Sytsma MD, Ruiz GM (2014) Small boats provide connectivity for nonindigenous marine species between a highly invaded international port and nearby coastal harbors. Manag Biol Invasion 5:97-112 